\title{
PENGARUH MODEL PEMBELAJARAN ASSURE DAN PENGETAHUAN AWAL TERHADAP HASIL BELAJAR IPA-FISIKA SISWA KELAS VIII SMPN 22 MATARAM
}

\author{
Haerul Muammar', Ahmad Hardjono², Gunawan² \\ 1) Program Studi Pendidika Fisika \\ ${ }^{2)}$ Program Studi Pendidika Fisika FKIP \\ Universitas Mataram \\ Mataram, Indonesia \\ Email: haerulm93@gmail.com
}

\begin{abstract}
This is an experimental research. This research aim to examine the effect of ASSURE learning model and prior knowledge on science learning outcome in class VIII of SMPN 22 Mataram. The population is entire students in class VIII SMPN 22 Mataram with VIIIB as experiment class and VIIIC as control class. Both divided into high and low prior knowldege group. This research use factorial design $2 \times 2$. Hypothesis test use two ways anava. We got that (1) learning model take significant effect on learning outcome that ASSURE model get higher score than konventional model, (2) prior knowledge take significant effect on learning out come that higher prior knowledge get higher score than the low one, and (3) there is no interaction between learning model and prior knowledge on learning outcome. N-Gain test shown that high prior knowledge of ASSURE class get most improvement result and low pior knowledge of conventional class get worst. It is better to continue this ASSURE learning model in research using another student characterictic analyze. High prior knowledge experiment class get improvement result in all sub-chapter. Low prior knowledge experiment class and high prior knowledge control class get most improvement in wave characteristic. Low prior knowledge control class get most improvement in vibration characteristic.
\end{abstract}

Keywords : learning model, ASSURE, prior knowledge, learning outcome

\section{Pendahuluan}

Ilmu Pengetahuan Alam (IPA) merupakan disiplin ilmu terkait dengan pengetahuan alam secara luas. Pengetahuan tersebut merupakan pengetahuan yang bersifat sistematis dan tersusun dengan menggabungkan gejala-gejala alam. Fisika sebagai cabang IPA tentunya juga memiliki karakteritik berupa proses, produk, dan sikap. Fisika sebagai proses berarti pemahaman mengenai bagaimana informasi ilmiah fisika dapat diperoleh dengan melakukan pengamatan, pengukuran, penyelidikan dan publikasi. Fisika sebagai produk berarti fisika sebagai kumpulan pengetahuan berupa fakta, konsep, prinsip, hukum, rumus, dan teori. Fisika sebagai sikap berarti penyampaian argumentasi dan ide melalui sikap-sikap ilmiah berupa objektif dan disiplin dalam melakukan proses fisika guna menghasilkan produk fisika. Dalam pembelajaran fisika, guru dituntut untuk memiliki kemampuan dalam menggunakan strategi pembelajaran yang efektif guna meningkatkan hasil belajar peserta didik agar optimal. Fisika dipandang sebagai suatu proses dan produk sehingga dalam pembelajarannya harus mempertimbangkan strategi atau metode pembelajaran yang efektif dan efisien [1].
Pembelajaran fisika di sekolah menengah pada kenyataannya menunjukkan hal yang berlawanan dengan penjelasan di atas. Secara umum, guru masih menggunakan model konvensional berupa ceramah saja sehingga peserta didik menjadi pasif dan suasana belajar menjadi membosankan. Banyak peserta didik sebenarnya mampu menyajikan tingkat hafalan yang baik terhadap materi ajar yang diterima namun pada kenyataannya mereka tidak memahaminya [2].

Alternatif yang dapat digunakan adalah model pembelajaran yang mampu membuat peserta didik menjadi aktif dan menghidupkan suasana kelas sehingga kelas tidak lagi menjadi membosankan. Hal tersebut dapat dilakukan dengan memanfaatkan teknologi sebagai media pembelajaran. Teknologi tidak hanya memudahkan dalam pembelajaran tetapi juga mampu meningkatkan rasa ingin tahu dan membuat peserta didik menjadi lebih tertarik untuk mengikuti pembelajaran. Salah satu model yang dapat digunakan yakni model pembelajaran ASSURE. Model ASSURE merupakan suatu model pembelajaran yang lebih berorientasi pada pemanfaatan media dan teknologi dalam menciptakan proses dan aktivitas pembelajaran yang diinginkan [3]. 
Salah satu karakteristik yang dianalisis pada model ASSURE adalah pengetahuan awal (prior knowledge). Pengetahuan awal merupakan tingkatan pengetahuan yang dimiliki peserta didik sebelum dimulainya pembelajaran. Pengetahuan awal seringkali dianggap sama oleh guru padahal kenyataannya belum tentu demikian. Menurut Pengetahuan awal memiliki dampak terbesar pada pembelajaran. Mereka yang memiliki pengetahuan awal yang baik dapat mempelajari lebih baik [4]. Peneliti memprediksi pengetahuan awal ikut berpengaruh terhadap hasil belajar sehingga peneliti memilih pengetahuan awal sebagai variabel moderator.

Penelitian ini dapat menjadi pertimbangan penggunaan model ASSURE untuk materi ataupun mata pelajaran yang lain serta perlu ditinjaunya pengetahuan awal peserta didik agar tidak dianggap sama untuk segala kondisi.

\section{TINJAUAN PUSTAKA}

\section{A. Model Pembelajaran ASSURE}

Model pembelajaran ASSURE merupakan model yang menggunakan teknologi secara sistematis dalam pembelajaran. Model ini berfokus pada perencanaan teknologi yang memudahkan guru dalam merancang dan melakukan perubahan pada lingkungan pendidikan yang nantinya akan mendukung peserta didik [5].

Kelebihan model ini yakni mampu menganalisis secara menyeluruh komponen-komponen dalam pembelajaran berupa karakteristik peserta didik, rumusan tujuan belajar, strategi dan kegiatan pembelajaran, hingga penilaian proses belajar. Selain itu juga mampu meningkatkan partisipasi aktif peserta didik dengan memanfaatkan peranan teknologi sehingga pembelajaran dapat menjadi lebih optimal [3].

ASSURE merupakan sebuah akronim. Sintaks model ASSURE adalah sebagai berikut.

1. Analyze (menganalisis karateristik peserta didik)

2. State (menentukan tujuan pembelajaran)

3. Select (memilih model, metode, dan media)

4. Utilize (menggunaan model, metode, dan media)

5. Require (mengajak peserta didik aktif)

6. Evaluation (evaluasi dan revisi)

\section{B. Model Konvensional}

Pembelajaran konvensional adalah suatu konsep belajar yang digunakan guru dalam membahas suatu pokok materi dengan cara biasa dimana guru sebagai sumber informasi utama dalam pembelajaran. Peserta didik lebih banyak mendengarkan penjelasan guru di depan kelas dan melaksanakan tugas jika guru memberikan latihan soal [6]. Pembelajaran ini masih dilaksanakan atas asumsi bahwa suatu pengetahuan dapat dipindahkan secara utuh dari pikiran guru ke peserta didik. Guru untuk memberikan intruksi atau ceramah selama pembelajaran berlangsung, sementara itu pserta didik hanya menerima pembelajaran secara pasif.

\section{Pengetahuan Awal}

Pengetahuan awal (prior knowledge) merupakan salah satu karakteristik peserta didik. Keberagaman latar belakang dan pengalaman menyebabkan pengetahuan awal masing-masing tidaklah sama. Mereka yang memiliki pengetahuan awal yang tinggi dapat belajar lebih baik daripada teman-temannya yang berkemampuan rata-rata dan rendah.

Pengetahuan awal yang didapatkan peserta didik sebelum pembelajaran mempengaruhi proses belajar secara signifikan. Jika pengetahuan awal baik, guru dan peserta didik lebih mudah untuk berinteraksi secara positif sehingga memudahkan pembelajaran. Terlebih lagi dalam pembelajaran fisika terdapat tingkatan-tingkatan pengetahuan yang saling terkait dan semakin kompleks di kemudian hari. Mereka yang memiliki kemampuan awal tinggi lebih mudah mengingat informasi yang telah mereka peroleh dan lebih cepat memahami materi yang telah dipelajari.

Guru perlu untuk mengetahui sejauh mana pengetahuan awal peserta didiknya sehingga jika pengetahuan awalnya sudah cukup baik, maka tidak perlu lagi dibahas dalam pembelajaran [3]. Peneliti memprediksi pengetahuan awal ikut berpengaruh pada hasil belajar peserta didik.

\section{Hasil Belajar}

Hasil belajar adalah hasil yang diperoleh peserta didik setelah dilakukan aktifitas belajar [7]. Hasil belajar terdiri dari kognitif, afektif dan psikomotor. Pada penelitian ini, hasil belajar hanya dibatasi pada ranah kognitif yang mengacu pada taksonomi Krathwol-Anderson meliputi C1-C6 (mengingat, memahami, mengaplikasi, menganalisis, mengevaluasi, dan membuat).

\section{Metode Penelitian}

Penelitian ini dilaksanakan pada kelas VIII SMPN 22 Mataram tahun pelajaran 2014/2015. Jenis penelitian ini adalah kuasi eksperimen. Desain penelitian menggunakan factorial design $2 \times 2$. Teknik 
pengambilan sampel yang digunakan adalah purposive sampling. Sampel pada penelitian ini adalah peserta didik kelas VIIIC sebagai kelas eksperimen dan peserta didik kelas VIIIB sebagai kelas kontrol. Kedua kelas dibagi lagi menjadi pengetahuan awal tinggi dan rendah.

Terdapat empat variabel yang menjadi fokus penelitian yaitu variabel bebas, variabel moderator, variabel terikat, dan variabel kontrol. Variabel bebas berupa model pembelajaran, variabel moderator berupa pengetahuan awal, variabel terikat berupa hasil belajar dan variabel kontrol berupa guru, materi, tujuan pembelajaran, dan instrumen tes. Teknik pengumpulan data pada penelitian ini adalah tes hasil belajar dan angket gaya belajar. Tes diberikan pada kedua kelas sedangkan angket hanya diberikan pada kleas kontrol sebagai informasi gaya belajar peserta didik. Tes berupa pilihan ganda sebanyak 30 soal diberikan pada kedua kelas. Tes ini telah diujicobakan kepada 30 peserta didik kelas IX di SMPN 22 Mataram tahun ajaran 2014/2015 dengan mengukur uji validitas, reliabilitas, tingkat kesukaran, dan daya beda soal. Analisis validitas instrumen menggunakan rumus product moment untuk menguji validitas soal dan rumus Spearmen-Brown untuk uji reliabilitas soal. Analisis data tes akhir menggunakan anava dua jalur. Peningkatan hasil belajar ditentukan dengan rumus uji $\mathrm{N}$-Gain ternormalisasi.

\section{Hasil dan PEMbahasan}

Kelas dibagi menjadi kelas eksperimen dan kontrol dengan kedua kelas dibagi menjadi pengetahuan awal tinggi dan rendah. Dengan demikian didapatkan kelas eksperimen pengetahuan awal tinggi, kels eksperimen pengetahuan awal rendah, kelas kontrol pengetahuan awal tinggi dan kelas kontrol pengetahuan awal rendah. Berdasarkan hasil analisis data, data keseluruhan kelas bersifat homogen dan terdistribusi normal. Peningkatan hasil belajar dinormalisasi dalam N-Gain. Berikut ditampilkan hasil tes akhir.

Tabel 1. Data Tes Akhir

\begin{tabular}{cccc}
\hline Kelas & $\begin{array}{c}\text { Pengetahuan } \\
\text { Awal }\end{array}$ & $\begin{array}{c}\text { Nilai } \\
\text { Rata- } \\
\text { Rata }\end{array}$ & N-Gain \\
\hline \multirow{2}{*}{ Ekperimen } & Tinggi & 84,23 & 0,60 \\
\multirow{2}{*}{ Kontrol } & Rendah & 72,10 & 0,50 \\
& Tinggi & 78,00 & 0,50 \\
& Redah & 55,60 & 0,30 \\
\hline
\end{tabular}

Data diatas menunjukkan bahwa kelas eksperimen pengetahuan awal tinggi memiliki nilai rata-rata tertinggi yakni 84,23 dan peningkatan hasil belajar paling baik dengan gain 0,60. Kelas kontrol pengetahuan awal rendah memiliki nilai rata-rata terendah yakni 55,60 dan juga peningkatan hasil belajar terendah dengan gain 0,30 .

Berikut ditampilkan hasil uji anava dua jalur dengan batuan SPSS 21.

Tabel 2. Hasil Uji Anava

\begin{tabular}{ccc}
\hline Kategori & Sig & Status \\
\hline Model & 0,00 & $\mathrm{H}_{0}$ ditolak \\
Pengetahuan Awal & 0,00 & $\mathrm{H}_{0}$ ditolak \\
Model*Pengetahuan Awal & 0,06 & $\mathrm{H}_{0}$ diterima \\
\hline
\end{tabular}

Berikut ditampilkan grafik pengaruh model pembelajaran ASSURE dan model pembelajaran konvensional terhadap hasil belajar IPA-Fisika peserta didik.

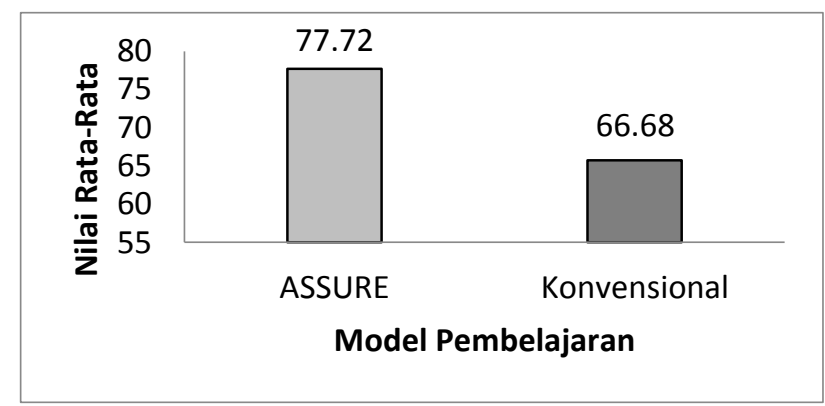

Gambar 1. Pengaruh Model Pembelajaran Terhadap Hasil Belajar

Model pembelajaran berpengaruh signifikan terhadap hasil belajar. Berdasarkan uji statistik didapat nilai sig sebesar 0,00 (sig $<0,05)$. Pada model ASSURE, peserta didik diberikan angket gaya belajar (VAK) sebelum dimulainya pembelajaran. Pada sintaks selanjutnya dalam memilih model pembelajaran, peneliti memilih model $V A K$ sebagai tindak lanjut dari gaya belajar $V A K$. Pada model $V A K$ ini, peneliti memberikan media power point untuk meningkatkan visual, membangun diskusi kelompok untuk meningkatkan audio dan memberikan eksperimen untuk meningkatkan kinestetic. Ketika pembelajaran berlangsung, peserta didik cukup antusias. Mereka yang dominan pada visual lebih banyak bertanya ketika diberikan gambar dan animasi. Mereka yang dominan pada audio lebih banyak bertanya dan menjawab ketika melakukan diskusi dan mereka yang dominan pada kinestetic lebih banyak bertanya pada saat melakukan eksperimen. Model ASSURE memang dapat 
membantu peserta didik untuk menjadi lebih aktif. Peserta didik kelas eksperimen memiliki nilai ratarata yang lebih baik dari peserta didik di kelas kontrol. Pada kelas kontrol, peneliti menggunakan pembelajaran model konvensional berupa ceramah dan kegiatan eksperimen. Pada saat pembelajaran, peserta didik pada kelas eksperimen lebih aktif bertanya ataupun berdiskusi dibandingkan dengan kelas kontrol. Peserta didik cukup antusias dalam memperhatikan penjelasan ketika dibantu dengan grafik, gambar dan animasi. Mereka lebih semangat dalam melakukan diskusi dan tidak segan untuk bertanya apa yang tidak dimengerti. Namun pada kelas kontrol tidak menunjukkan hal demikian. Mereka lebih senang mengobrol sendiri dan terlihat bosan dalam mengikuti pembelajaran. Hal ini sesuai dengan teori bahwa model pembelajaran ASSURE lebih baik dari model konvensional. Penelitian serupa juga menunjukkan bahwa model ASSURE dapat mempengaruhi hasil belajar IPA peserta didik secara signifikan [8], [9]. Pada penelitian lain menjelaskan rendahnya hasil belajar pada model pembelajaran konvensional karena peserta didik dalam proses pembelajaran hanya mendengar penjelasan materi dari guru dan mencatat materi dari buku paket atau guru hanya berceramah dalam memberikan materi [10].

Berikut ditampilkan grafik pengaruh pengetahuan awal terhadap hasil belajar IPA-Fisika peserta didik.

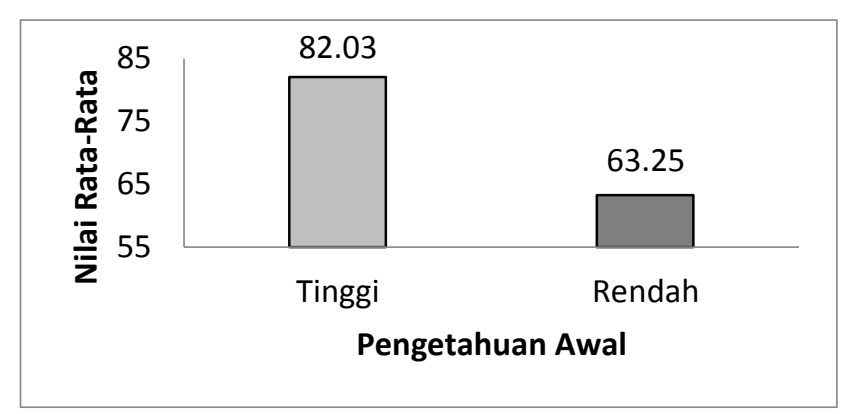

Gambar 2. Pengaruh Pengetahuan Awal Terhadap Hasil Belajar

Pengetahuan awal berpengaruh signifikan terhadap hasil belajar. Berdasarkan uji statistik didapat nilai sig sebesar $0,00(\mathrm{sig}<0,05)$. Tabel 1 menunjukkan pengetahuan awal tinggi pada kelas eksperimen dan kontrol memiliki $\mathrm{N}$-Gain lebih tinggi dari pengetahuan awal rendah. Mereka yang memiliki pengetahuan awal tinggi lebih mudah menyesuaikan diri dalam pembelajaran. Terlebih lagi pada saat diberikan latihan soal, mereka lebih aktif dan antusias ketika maju ke depan untuk menuliskan jawaban.
Peserta didik dengan pengetahuan awal rendah sebagian besar tidak aktif dan tidak menguasai pembelajaran dengan baik. Pengetahuan awal dalam belajar fisika akan menentukan kelancaran peserta didik dalam memahami materi yang sedang dipelajarinya sehingga peserta didik yang memiliki pengetahuan awal tinggi memiliki hasil belajar yang lebih baik daripada peserta didik yang memiliki pengetahuan awal rendah. Penelitian lain juga menunjukkan hal serupa bahwa hasil belajar kelompok yang memiliki pengetahuan awal tinggi, lebih tinggi dari kelompok yang memiliki pengetahuan awal rendah sehingga pengetahuan awal memiliki peranan yang sangat penting dalam proses pembelajaran dan memiliki pengaruh yang signifikan terhadap hasil belajar [11],[12],[13].

Tidak ada interaksi model pembelajaran dan pengetahuan yang terjadi pada peneilitian ini. Tabel 2 menunjukkan nilai sig sebesar 0,06 (sig > 0,05). Model pembelajaran dan pengetahuan awal masingmasing berpengaruh signifikan terhadap hasil belajar namun pada keduanya tidak terjadi interaksi. Hal ini dapat terjadi karena mereka yang memiliki pengetahuan awal tinggi akan dapat menghasilkan hasil belajar yang tinggi pula meski diberikan model pembelajaran yang berbeda. Dengan demikian, maka pengetahuan awal dan model belajar bersifat independen. Pengaruh yang diberikan model pembelajaran terhadap hasil belajar merupakan pengaruh yang berdiri sendiri dan tidak berhubungan dengan pengetahuan awal, begitu pula sebaliknya. Pengaruh yang diberikan pengetahuan awal terhadap hasil belajar adalah pengaruh yang berdiri sendiri dan tidak berhubungan dengan model pembelajaran. Pada pembelajaran fisika dengan menggunakan model pembelajaran apapun, semakin tinggi pengetahuan awal peserta didik, akan semakin tinggi pula hasil belajarnya. Berikut ditampilkan grafik interaksi model pembelajaran dan pengetahuan awal. 


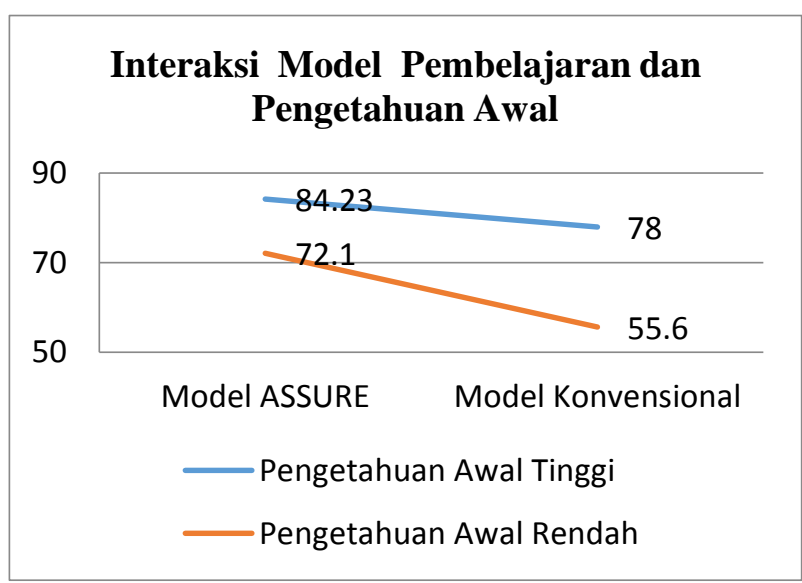

Gambar 3. Interaksi Model Pembelajaran dan Pengetahuan Awal.

Secara statistik, suatu variabel dikatakan berinteraksi dengan variabel lainnya jika keduanya memiliki titik pertemuan [14]. Pada gambar 3, terlihat bahwa tidak ada titik temu antara kedua garis yang menghubungkan kedua variabel. Pada penelitian ini, titik temu akan muncul jika salah satu kelas yang memiliki pengetahuan awal rendah mampu mencapai hasil belajar yang lebih tinggi dari mereka yang memiliki pengetahuan awal tinggi pada kelas yang sama. Padahal secara teori tentu tidak dapat terjadi. Hal tersebut juga didukung dengan nilai gain yang diperoleh masing-masing kelompok. Hal ini menunjukkan bahwa secara teori ataupun nilai di lapangan tidak memungkinkan adanya interaksi model pembelajaran dan pengetahuan awal.

Terkait dengan peningkatan hasil belajar, tiap kelas memiliki peningkatan pada sub materi yang berbeda. Materi yang diajarkan pada penelitian ini adalah getaran dan gelombang. Materi tersebut dibagi menjadi empat sub materi yakni karakteristik getaran, aplikasi rumus getaran, karakteristik gelombang, dan aplikasi rumus gelombang. Karakteristik getaran dan gelombang berada pada ranah $\mathrm{C} 1$ dan $\mathrm{C} 2$ sedangkan aplikasi rumus getaran dan gelombang berada pada ranah C4, C5, dan C6. Berikut ditampilkan analisis jawaban tiap kelas dengan "a" sebagai karakteristik getaran, "b" sebagai aplikasi rumus getaran, "c" sebagai karakteristik gelombang dan "d" sebagai aplikasi rumus gelombang.

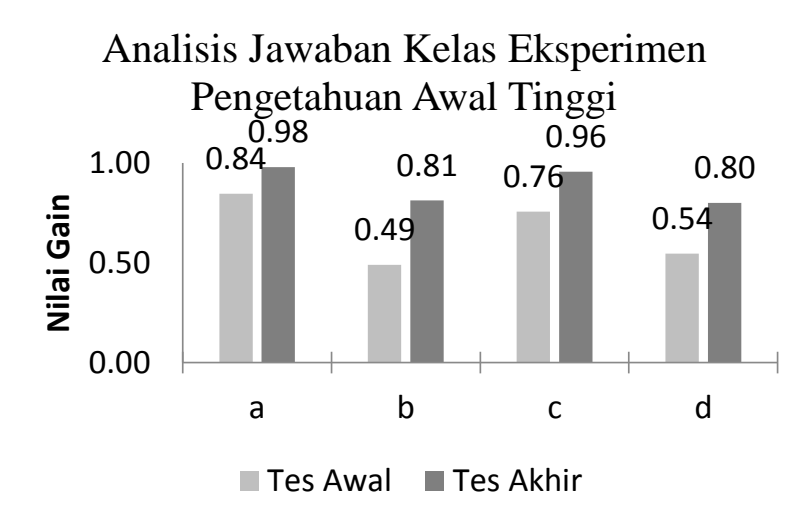

Gambar 4. Analisis Jawaban Kelas Eksperimen Pengetahuan Awal Tinggi

Gambar diatas menunjukkan bahwa kelas eksperimen pengetahuan awal tinggi sudah memahami karakteristik getaran dan gelombang dengan baik sebelum diberi perlakuan sedangkan mereka masih belum memahami soal hitungan pada aplikasi rumus getaran dan gelombang. Setelah diberikan perlakuan, terjadi peningkatan yang signifikan terutama pada sub materi aplikasi rumus getaran dan gelombang, Hal ini menunjukkan model dan metode yang digunakan cukup membantu peserta didik dalam memahami masalah khususnya pada bagian hitungan.

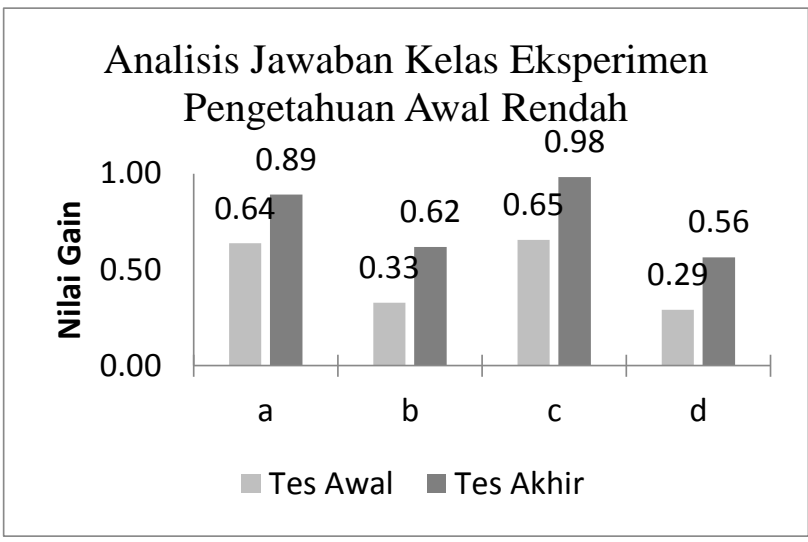

Gambar 5. Analisis Jawaban Kelas Eksperimen Pengetahuan Awal Rendah

Gambar diatas menunjukkan kelas eksperimen dengan pengetahuan awal rendah menunjukkan hal berbeda. Sebelum diberi perlakuan, kelas ini memiliki pemahaman yang baik pada karakteristik getaran saja namun tidak untuk sub materi yang lain. Setelah diberi perlakuan, kelas ini mengalami peningkatan pada semua sub materi namun tidak sebaik kelas eksperimen dengan pengetahuan awal tinggi terutama pada bagian aplikasi rumus getaran dan gelombang yang berbasis pada hitungan. Tetapi pada sub materi 
karakteristik gelombang, kelas ini meningkat sedikit lebih baik.

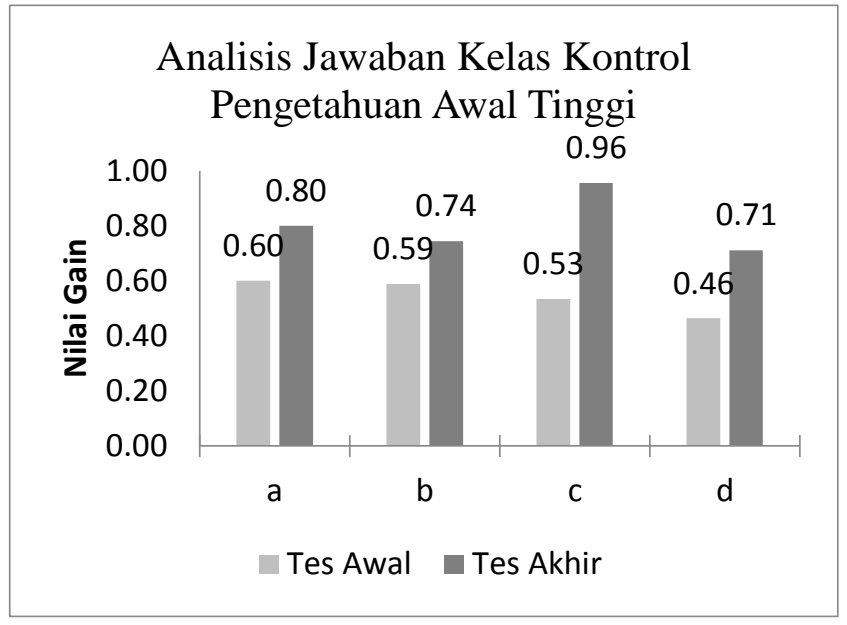

Gambar 6. Analisis Jawaban Kelas Kontrol Pengetahuan Awal Tinggi

Gambar diatas menunjukkan bahwa kelas kontrol dengan pengetahuan awal tinggi memahami dengan baik semua sub materi getaran dan gelombang sebelum diberi perlakuan. Namun setelah diberi perlakuan, sub materi karakteristik gelombang mengalami peningkatan paling besar dibanding sub materi lainnya.

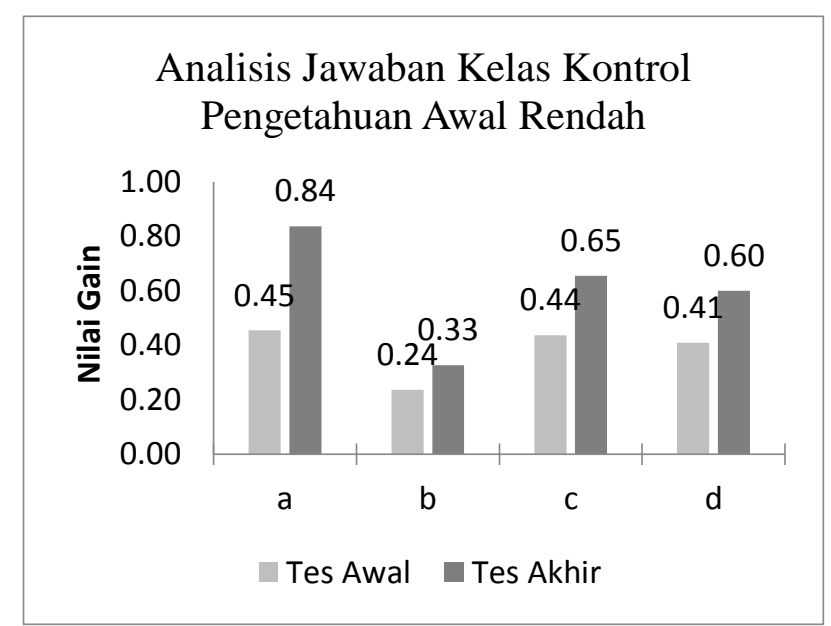

Gambar 7. Analisis Jawaban Kelas Kontrol Pengetahuan Awal Rendah

Gambar diatas menunjukkan bahwa kelas kontrol dengan pengetahuan awal rendah tidak memahami keempat sub materi sebelum diberi perlakuan. Setelah diberi perlakuan, hanya sub materi karakteristik getaran yang mengalami peningkatan dengan baik sedangkan pada sub materi aplikasi rumus getaran tidak terjadi peningkatan yang signifikan. Hal ini berarti kelas ini masih mengalami kesulitan pada penggunaan persamaan pada getaran.

\section{Penutup}

Berdasarkan hasil penelitian dan pembahasan maka disimpulkan bahwa terdapat pengaruh model pembelajaran terhadap hasil belajar, terdapat pengaruh pengetahuan awal terhadap hasil belajar, dan tidak terdapat interaksi model pembelajaran dan pengetahuan awal. Terkait model pembelajaran, model ASSURE lebih baik dari model konvensional. Hal ini dapat dilihat bahwa nilai rata-rata model ASSURE lebih tinggi dari model konvensional. Terkait dengan pengetahuan awal, peserta didik dengan pengetahuan awal tinggi memiliki hasil belajar yang lebih baik dari pengetahuan awal rendah. Hal ini terlihat dari nilai pengetahuan awal tinggi lebih tinggi dari pengetahuan awal rendah. Dari perhitungan $N$-Gain ternormalisasi secara keseluruhan dan per sub materi pada tiap kelas, dapat disimpulkan bahwa peserta didik kelas eksperimen pengetahuan awal tinggi mengalami peningkatan yang signifikan untuk semua sub materi. Peserta didik kelas eksperimen pengetahuan awal rendah dan kelas kontrol pengetahuan awal tinggi mengalami peningkatan terbaik pada sub materi karakteristik gelombang. Kelas kontrol pengetahuan awal rendah mengalami peningkatan terbaik pada sub materi karakteristik gelombang.

Pada penelitian selanjutnya, diharapkan dapat dilakukan analisis lain pada karaksteristik peserta didik.

\section{UCAPAN TERIMA KASIH}

Terima kasih penulis ucapkan untuk bapak Didik Syamsul Hadi, S.Pd selaku kepala SMPN 22 Mataram serta bapak Ida Bagus Bangli S, S.Pd selaku guru kelas dan seluruh peserta didik kelas VIIIB dan VIIIC tahun ajaran 2014/2015 yang telah ikut serta dalam penelitian ini.

\section{REFERENSI}

[1] Hikmawati dan Gunada, I W. 2013. Kajian Fisika SMA. Mataram: Unram-Press.

[2] Suprijono, A. 2012. Cooperatif Learning: Teori dan Aplikasi PAIKEM. Yogyakarta: Pustaka Pelajar.

[3] Pribadi, B.A. 2011. Model ASSURE untuk Mendesain Pembelajaran Sukses. Jakarta: PT Dian Rakyat.

[4] Walberg, H. J. 2011. Improving Student Learning Action Principles for Families, School, Districts, and States. United States of America: Information Age Publishing. 
[5] Heinich, R., Molenda, M., Russel, J.D., and Smaldino, S E.1996. Instructional Media and Technologies for Learning $5^{\text {th }} E d$. New York: Printice-Hall, Inc.

[6] Djamarah, S.B. 1994. Prestasi Belajar dan Kompetensi Guru. Surabaya: Usaha Nasional.

[7] Djamarah, S.B. dan Zain, A. 2006. Strategi Belajar Mengajar. Jakarta: PT Asdi Mahastya.

[8] Giarti, S. 2012. Model Pembelajaran ASSURE untuk Meningkatkan Hasil Belajar. Journal Scholaria. 2(1). 195-215.

[9] Harijanti N.S. 2007. Peningkatan Partisipasi dan Kreativitas Siswa Pada Mata Pelajaran Geografi dengan Model ASSURE di Kelas XD Man Tempursari Mantingan Ngawi. Tesis Program Pascasarjana Universitas Sebelas Maret. Tesis tidak diterbitkan.

[10] Rasyid, A., Pasaribu M., dan Kamaluddin. 2014. Pengaruh Model Pembelajaran Kooperatif Tipe NHT (Numbered Heads Together) dan Kemampuan Awal Terhadap Hasil Belajar Siswa Pada Mata Pelajaran Fisika Di Smp Negeri 2 Poso. Jurnal Pendidikan Sains Pascasarjana Universitas Tadulako. 2(1). 1-8

[11] Dharma, I N., Sadra I W., dan Sariyasa, I W. 2013. Pengaruh Pendidikan Matematika Realistik Terhadap Pemahaman Konsep Dan Daya
Matematika Ditinjau Dari Pengetahuan Awal. Jurnal Universitas Pendidikan Ganesha. 2(1). 110

[12] Leatemia, M. 2013. Pengaruh Strategi SQ4R Tipe Bantuan Multimedia vs Buku Teks, Pengetahuan Awal, Gaya Belajar Kolb terhadap Hasil Belajar. Jurnal Teknologi Pembelajaran UNM. 1(4). 1-11.

[13] Parnata, I K., dan Suandi, I K. 2010. Implementasi Cooperative Learnin dalam Pembelajaran Sistem Akuntasi untuk Meningkatkan Hasil Belajar Mahasiswa Ditinjau dari Prior Knowledge Mahasiswa. Ragam Jurnal Pengembangan Humaniora. 10(2). 98-105.

[14] Cardinal, R N. 2004. Anova In Practice And Complex Anova Designs. United States of America: Thompson Learning.

\section{Biografi Penulis}

Haerul Muammar, S.Pd, lahir di Mataram 28 Mei 1993. Tahun 2005 lulus di SDN 2 Ampenan dan tahun 2008 lulus di SMPN 2 Mataram. Tahun 2011 lulus di SMAN 1 Mataram dan melanjutkan pendidikan S-1 di Universitas Mataram pada program studi pendidikan fisika hingga meraih gelar sarjana tahun2015. 